\title{
Trauma leagues: an alternative way to teach trauma surgery to medical students
}

\section{Ligas do trauma: um caminho alternativo para ensinar cirurgia do trauma aos estudantes de medicina}

Romeo Lages Simões ${ }^{1}$; Fernando Antônio Martins Bermudes ACBC-ES²; Hudson Silva Andrade ${ }^{3}$; Fllipe Machado Barcelos 3 ; Breno Pinheiro Rossoni3i; Gustavo Peixoto Soares Miguel, TCBC-ES²; Carlos Alberto de Castro Fagundes, ACBC-ES ${ }^{4}$; Gustavo Pereira Fraga, TCBC-SP 1

\section{A B S S T R A C T}

\begin{abstract}
Objective: to compare the knowledge of medical students between those who are members of the Trauma League (TL) and those from a non-Trauma League (NTL) group of the Federal University of Espírito Santo (UFES). Methods: cross-sectional, analytical and descriptive study. Two knowledge tests, with 30 questions each, were applied to students from $3^{\text {rd }}$ to $12^{\text {th }}$ period, randomly selecting five students per period, with 50 students in the TL group and 50 in NTL. The questionnaire topics were: pre-hospital care, the mnemonic $A B C D E$ trauma sequence, advanced trauma and imaging. The students' performances were evaluated by graduationperiod group: basic ( $3^{\text {rd }}-5^{\text {th }}$ period), intermediary/clinical $\left(6^{\text {th }}-8^{\text {th }}\right)$ and internship $\left(9^{\text {th }}-12^{\text {th }}\right)$. Results: in the first test the average accuracy of the TL group was $20.64 \pm 3.17$, while for the NTL group, it was $14.76 \pm 5.28(p<0.005)$. In the second test the average accuracy for the TL group was $21.52 \pm 3.64$, while for the NTL group, the average was $15.36 \pm 29.5(p<0.005)$. When divided into graduation periods, it was observed that the TL group showed a higher average across all three groups $(p<0.05)$ in both tests. Conclusion: the students who attended the academic league activities have greater knowledge of the issues that are considered relevant to patient trauma care. In all periods of undergraduate academic training, the TL group had greater knowledge of the subject than the NTL group.
\end{abstract}

Key words: Trauma. Students, Medical. Teaching. General Surgery.

\section{INTRODUCTION}

\begin{abstract}
A round the world it is estimated that, annually, approximately five million people die from external causes (injuries or violence), representing $9 \%$ of worldwide mortality'. Trauma is the leading cause of death among young people aged from 5 to 44 years, causing a loss of many years of productive lives, when compared to cardiovascular and neoplastic conditions together ${ }^{2}$. In Brazil, trauma occupies the third position among the most frequent causes of death, surpassed only by cardiovascular and neoplastic conditions, representing $12.5 \%$ of all deaths ${ }^{3,4}$. It is estimated that trauma was responsible for approximately 2,347,082 deaths between the years 1980 and $2011^{5}$. While these numbers are alarming, in Brazil, there is not yet an organized system of care for these patients ${ }^{6}$. There are few training centers for skilled medical professionals of trauma patient care, and few medical schools have Trauma Surgery as a discipline. Another challenge is to
\end{abstract}

develop a standard training model for the trauma surgeon ${ }^{7}$.

In Brazil, a very controversial concept within undergraduate medicine is a "parallel curriculum". Every effort to include practical and/or theoretical exercises in academic activities with the intent to acquire clinical experience, even if they are not included in the official curriculum, should be defined as part of a "parallel curriculum"8-12. One way of implementing the "parallel curriculum" focuses on the role of the Academic Leagues, which currently have the greatest responsibility for the learning of specific themes within Brazilian universities. The Academic Leagues consist of groups of students from different years of medical education, called ligands, which, under the supervision of professionals, look to deepen knowledge and extend practice of the subject, focusing on the performance of the triad: education, research and extention ${ }^{11,12}$. Thus, in an extracurricular way, the Academic Leagues emerge as an important agent in the spread of knowledge concerning a subject of great interest and

1. Division of Trauma Surgery, Faculty of Medical Sciences, University of Campinas (Unicamp), Campinas, SP, Brazil; 2. Clinical Surgery Department, Federal University of Espírito Santo (UFES), Brazil; 3. Faculty of Medicine Federal University of Espírito Santo (UFES); 4. State Hospital Dr. Jayme dos Santos Neves (HEJSN), ES, Brazil. 
relevance to students, however, they can induce a premature specialization and become dangerous during training in the absence of competent student supervision ${ }^{11,12}$.

The role of the trauma leagues has become an important teaching device in most medical schools around the country, mainly in universities that do not have trauma as a discipline. Student participation in a league is voluntary, and promotes enhanced learning in the area of surgery and emergencies. Allowing medical academics to become involved with the trauma leagues provides greater contact with the subject, therefore providing constant updates and practical activities that will enhance surgical and other skills, of both the students and the future residents of general and trauma surgery ${ }^{13}$

So the argument proposed by this study was needed in order to assess the degree of knowledge of medical students, and the issues that are discussed during the medical training of these future physicians. Understanding their training and their weak points are key to ensuring dignified care to trauma patients and raising their prognoses.

The study had, as a general objective, the comparison of the knowledge of medical students between those who are members of the Trauma League (TL) and those from a non-Trauma League (NTL) group of the Federal University of Espírito Santo (UFES).

\section{METHODS}

A cross-sectional, descriptive and analytical study, involving medical students belonging to UFES from the 3rd to 12th period of study. The study was approved by the Ethics Committee on Human Research of the University Hospital Cassiano Antonio de Moraes (HUCAM) and registered with the Ministry of Health Brazilian Platform, CAAE 15774013.9.0000.5071, voucher number 034010/ 2013.

The research participants signed a Statement of Informed Consent (SIC) in order to be included in the study and their identities were preserved, assigning an identification code to each. Those students who had attended the activities of the league, but who did not frequent sufficiently to be approved as members, as well as medical students who were not UFES students, but were part of the trauma league, were excluded from the study.

Test assessments were applied to the students from each academic period, from the 3rd to 12th, who were invited to participate voluntarily in the study and were divided into: Group A as students from the TL group, and group B as NTL students. From these assessments were drawn five students from each period, of each group, constituting 50 assessments from each. The same method was applied six months after the first assessment, with the same groups of students, thus constituting Tests 1 and 2

Both test evaluations followed a pre-established general format, with 30 questions each, and evenlydistributed important subjects on the care of trauma victims: questions 1 to 4 pertaining to pre-hospital care; 5 to 8 pertaining to item $A$ (airway and cervical spine immobilization); 9 to 12 pertaining to item $B$ (breathing); 13 to 16 referring to item $C$ (circulation); 17 to 20 pertaining to item D (neurological evaluation); 21 to 24 pertaining to item E (exposure and hypothermia prevention); 25 to 28 pertaining to advanced trauma procedures; and questions 29 to 30 pertaining to radiology for trauma. Both assessments were carried out in 2013 , with a six-month interval between them.

The performances of students per graduation period group were evaluated by dividing as follows: basic (3rd to 5th periods), intermediary (6th to 8th periods) and internship (9th to 12th periods).

For a correlation between the independent sample variables $T L$ and NTL, as much as for general assessment per group, as well as assessment per question group, and also for assessment per graduation period group, the average Student-T test was applied to assess whether there was statistical significance in the results, adopting a value of $p<0.05$ between the groups, and a confidence interval $(\mathrm{Cl})$ of $95 \%$ for the means.

\section{RESULTS}

Out of a total of 30 questions in Test 1, the TL group responded correctly to, on average, 20.64, whereas the NTL group achieved a mean of $14.76(p<0.005)$. The mean test results for independent samples showed a significant difference between the groups. For, in Test 2 , the TL group achieved, on average, 21.52 correct answers, and the NTL group achieved a mean of $15.36(p<0.005)$. The differences between the means for the TL and NTL groups, in both Tests 1 and 2, are shown in figure 1, noting a 95\% confidence interval for the mean quantity of correct answers.

The result of the mean test for independent samples indicates that there is a significant difference between the TL and NTL groups, for the question theme groups, regarding Test 1 . It can also be seen that, in all the answer groups, the means of numbers of correct answers were greater for the TL group than for the NTL group (Table 1). The mean number of correct answers per theme in Test 2 were greater in the TL group and there wasn't a significant difference between the groups for the question group themes "Airways and cervical protection" and "Trauma imaging" (Table 2). With reference to the medical study curricular periods, shows a significant difference between the TL and NTL groups in all three graduation stages in Test 1 and Test 2 (Table 3). 


\section{Test 1}

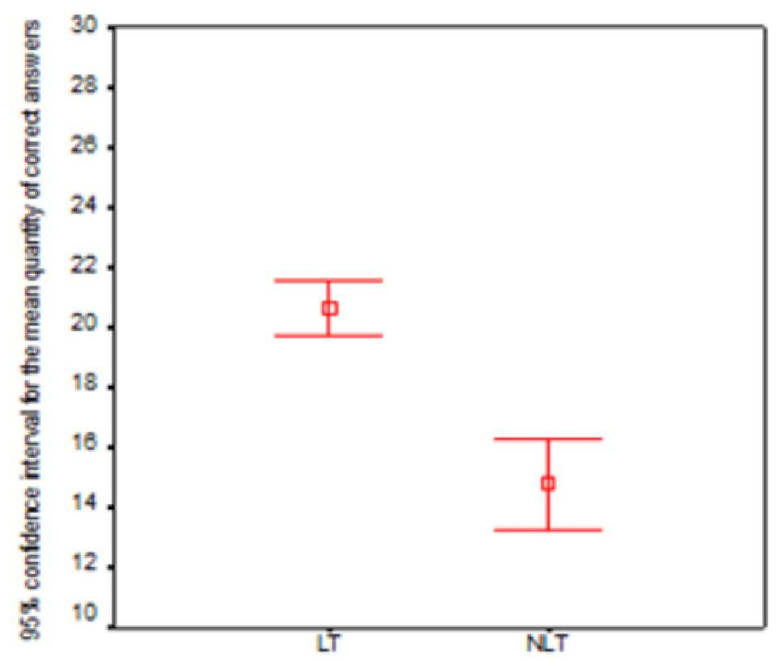

Test 2

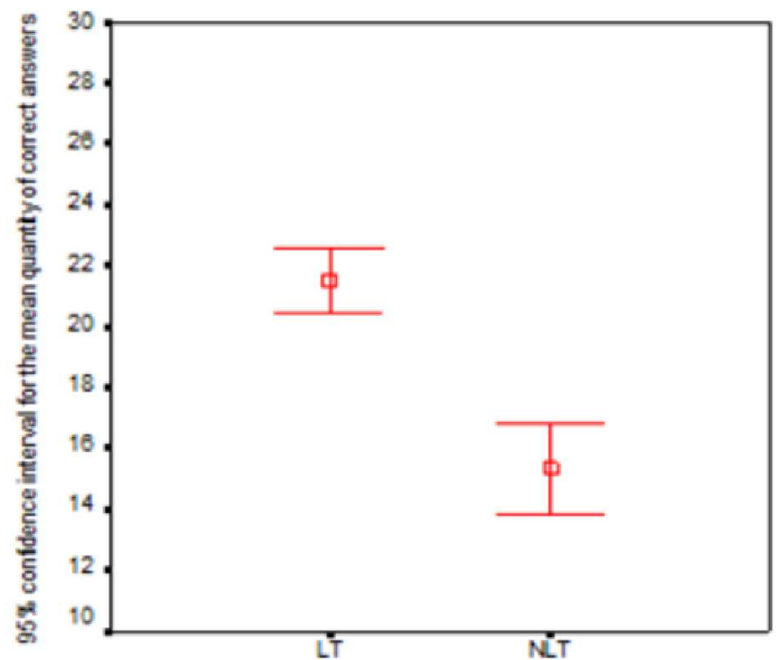

Figure 1 - Chart showing means of total correct answers between groups TL and NTL, in Tests 1 and 2.

\section{DISCUSSION}

There are no standardized methods of assessment to evaluate the training role of trauma leagues in our country, nor the methodology employed in the training of students, nor in the evaluation of knowledge provided by them. League student participation is voluntary and it complements the curricular activities, seeking to stimulate learning about specific areas and student self-learning. Some studies that purport to assess the knowledge of academics, seek to do so through descriptive cross-sectional studies, after analyzing the responses of self-administered questionnaires regarding specific subjects ${ }^{14,15}$. This study aims to assess the knowledge of UFES medical students,

Table 1 - Mean number of correct answer statistics, per question theme group, each with 4 questions, comparing TL and NTL groups, in Test 1.

\begin{tabular}{|c|c|c|c|c|}
\hline Theme group & Group & Mean & Standard deviation & $p$-Value \\
\hline \multirow[t]{2}{*}{ Pre-hospital care } & $\mathrm{TL}$ & 2.58 & 0.81 & $0.000 *$ \\
\hline & NTL & 1.52 & 0.89 & \\
\hline \multirow[t]{2}{*}{ Airways and cervical protection } & TL & 3.48 & 0.79 & 0.001 * \\
\hline & NTL & 2.82 & 1.14 & \\
\hline \multirow[t]{2}{*}{ Breathing } & TL & 2.30 & 0.99 & $0.024 *$ \\
\hline & NTL & 1.84 & 1.02 & \\
\hline \multirow[t]{2}{*}{ Circulation } & TL & 2.60 & 0.93 & $0.002 *$ \\
\hline & NTL & 1.96 & 1.07 & \\
\hline \multirow[t]{2}{*}{ Neurology } & $\mathrm{TL}$ & 2.56 & 0.91 & $0.000 *$ \\
\hline & NTL & 1.70 & 1.11 & \\
\hline \multirow[t]{2}{*}{ Exposure and hypothermia control } & $\mathrm{TL}$ & 3.38 & 0.67 & $0.000 *$ \\
\hline & NTL & 2.04 & 1.24 & \\
\hline \multirow[t]{2}{*}{ Advanced trauma procedures } & TL & 2.54 & 0.89 & $0.014 *$ \\
\hline & NTL & 2.04 & 1.11 & \\
\hline \multirow[t]{2}{*}{ Trauma imaging } & $\mathrm{TL}$ & 1.20 & 0.81 & $0.022 *$ \\
\hline & NTL & 0.84 & 0.74 & \\
\hline
\end{tabular}

* $p$-Value $<0.05$ 
Table 2 - $\quad$ Statistics for mean numbers of correct answers, per question-theme group, each with four questions, comparing the TL and NTL groups, in Test 2.

\begin{tabular}{|c|c|c|c|c|}
\hline Theme group & Group & Mean & Standard deviation & $p$-Value \\
\hline \multirow[t]{2}{*}{ Pre-hospital care } & $\mathrm{TL}$ & 2.16 & 0.91 & $0.000 *$ \\
\hline & NTL & 1.36 & 1.14 & \\
\hline \multirow[t]{2}{*}{ Airways and cervical protection } & $\mathrm{TL}$ & 3.66 & 0.59 & 0.475 \\
\hline & NTL & 3.56 & 0.79 & \\
\hline \multirow[t]{2}{*}{ Breathing } & $\mathrm{TL}$ & 2.98 & 0.98 & $0.017 *$ \\
\hline & NTL & 2.46 & 1.15 & \\
\hline \multirow[t]{2}{*}{ Circulation } & $\mathrm{TL}$ & 2.96 & 0.83 & $0.000 *$ \\
\hline & NTL & 1.84 & 1.06 & \\
\hline \multirow[t]{2}{*}{ Neurology } & $\mathrm{TL}$ & 2.96 & 0.86 & $0.000 *$ \\
\hline & NTL & 1.88 & 1.41 & \\
\hline \multirow[t]{2}{*}{ Exposure and hypothermia control } & $\mathrm{TL}$ & 3.02 & 0.89 & $0.000 *$ \\
\hline & NTL & 2.00 & 1.31 & \\
\hline \multirow[t]{2}{*}{ Advanced trauma procedures } & $\mathrm{TL}$ & 2.62 & 1.05 & $0.000 *$ \\
\hline & NTL & 1.30 & 0.91 & \\
\hline \multirow[t]{2}{*}{ Trauma imaging } & $\mathrm{TL}$ & 1.16 & 0.96 & 0.306 \\
\hline & NTL & 0.96 & 0.99 & \\
\hline
\end{tabular}

* $p$-Value $<0.05$

comparing the degrees of knowledge of academics in both TL and NTL groups, by way of multiple-choice tests, as other studies in literature have done ${ }^{14-17}$.

It was observed in this study that both Tests 1 and 2 prove that the performance of the TL group was better than the NTL group, with a statistical significance between the results ( $p<0.001$ in Tests 1 and 2$)$. In a study of third-year medical students from a U.S. university, two groups of students were compared; those who had had lessons about $\mathrm{ATLS}^{\circledR}$, and those who had completed the same training stage, but without these lessons ${ }^{16}$. It was observed that the students in the first group had a better performance and greater retention of knowledge after seven weeks, concluding that the ATLS ${ }^{\circledR}$ content should be adopted as a minimum prerequisite in all medical schools ${ }^{16}$. An article in a systematic literature review evaluated the educational impact that the $\mathrm{ATLS}^{\circledR}$ course has in the training of physicians, residents and medical students ${ }^{18}$. The article showed that the ATLS ${ }^{\circledR}$ courses significantly improved the knowledge and clinical trauma-care skills of the participants, as well as improving their defining ability of definitive behavior.

The better performance of the academics who were linked to the trauma league is probably explained by their dedication and interest in extracurricular learning, through theoretical activities developed by the league, as well as organization and participation of symposia and conferences of the Brazilian Committee of Trauma Leagues (CoBraLT) and the Brazilian Society of Integrated Trauma Care (SBAIT), and also by their taking part in practical activities linked to referral hospitals for trauma care.

Even with evidence of knowledge gains within the two groups over the six months, it was noticed that the

Table 3 - $\quad$ Mean numbers of correct answers between the TL and NTL groups per graduation period (basic, intermediary and internship) in Test 1 and Test 2.

\begin{tabular}{|c|c|c|c|c|c|c|c|c|c|c|}
\hline \multirow{3}{*}{ Stage } & \multicolumn{8}{|c|}{ Group } & & \\
\hline & \multicolumn{4}{|c|}{$\begin{array}{c}\mathrm{TL} \\
\text { Mean (std. dev.) }\end{array}$} & \multicolumn{4}{|c|}{$\begin{array}{c}\text { NTL } \\
\text { Mean (std. dev.) }\end{array}$} & \multicolumn{2}{|c|}{$p$-Value } \\
\hline & Tes & & Tes & t 2 & $\mathrm{Te}$ & st 1 & & st 2 & Test 1 & Test 2 \\
\hline Basic & 19.5 & $(2.1)$ & 18.9 & (2.1) & 9.3 & (3.4) & 10.7 & (3.5) & $0.000 *$ & $0.000 *$ \\
\hline Intermediary & 19.3 & (3.6) & 22.3 & (4.0) & 13.7 & (3.6) & 14.5 & (5.0) & $0.000 *$ & $0.000 *$ \\
\hline Internship & 22.5 & $(2.8)$ & 22.9 & (3.3) & 19.6 & $(2.2)$ & 19.4 & (3.2) & $0.001 *$ & $0.002 *$ \\
\hline
\end{tabular}

* $p$-Value $<0.05$ 
TL group maintained a statistically significant improvement when compared to the NTL group $(p<0.005)$ for both tests. This study chose to conduct two evaluation tests, separated by six months, to assess the learning curve of the students in each group, since literature suggests that in such a period, medical students or doctors who undergo the ATLS ${ }^{\circledR}$ course show a decline in their knowledge if they don't re-attend the course ${ }^{17}$.

The study also noted that for the two tests, the TL group had a higher mean of correct answers relating to the theme of pre-hospital care, showing a statistically significant difference between the groups. This suggests that the topic is rarely discussed during the training of medical students, which is reinforced by the present study since, although the average accuracy for the TL group was statistically significantly higher than the NTL group in the two tests, it was realized that the average accuracy for questions relating to pre-hospital care was low for both groups in both tests. The understanding of pre-hospital care is vital, since it can ensure better prognoses for severe trauma victims through immediate stabilization of the patients, and ensure that they arrive at hospital alive ${ }^{19}$.

With reference to the theme of "airways and cervical immobilization" (item A) in Test 1, the students of the TL group had a higher accuracy mean than the NTL group, with a statistically significant difference between the groups. However, in Test 2, this trend was not observed, since the average accuracies of both groups were similar, with no statistical difference between them. The mastery of the subject by both groups shows that there is a tendency for an appreciation of the importance of addressing both the airway and protection of the cervical spine, quickly and safely, since the loss of the airway, and so breathing, is the cause that most quickly leads to death ${ }^{20}$. For the group of questions relating to items $B, C$ and $D$, for both tests, the $T L$ group maintained the highest accuracy average in relation to the NTL group, with a statistical significance between the groups. Regarding the assessment of the question group item $\mathrm{E}$ (exposure and hypothermia prevention) in both tests, the TL group performed better, with a statistically significant difference between the groups. Hypothermia is a pre-hospital physiologic parameter predictor of the need for damage control surgery ${ }^{21}$. A study of simulated trauma involving multiple victims, with 40 patients, showed that in $50 \%$ of the simulated cases, this aspect was carried out in an inadequate way ${ }^{22}$. The present study corroborates this finding, since the NTL students answered correctly, on average, two of the four questions in both tests, which represents $50 \%$ of the questions of item $\mathrm{E}$.

When evaluating the performance of students in relation to the question group "advanced trauma procedures", we found once again that the TL group had a higher accuracy average in relation to the NTL group, with a statistically significant difference between the groups. Even so, it was found that the accuracy average for both groups was low. The understanding of some subjects is extremely important in determining good prognoses of trauma patients. Among the issues addressed in the questions were: the triad coagulopathy / hypothermia / metabolic acidosis, the strategy of "permissive hypotension", the application of damage control surgery and the non-operative treatment of blunt abdominal trauma to solid organs.

An analysis of the results comparing the performance of the TL and NTL groups by undergraduate periods, corresponding to the basic, intermediary and internship stages, in both tests, showed that for the three period groups, the TL students consistently showed a higher accuracy average in relation to the NTL group. In other words, the data obtained in this study corroborate with literature, since the practices of trauma and emergency surgery continue to evolve, leading to more effective treatments and better results, while at the same time demanding continued education for surgeons, residents and students ${ }^{23}$. In a study of 1041 doctors who attended the ATLS ${ }^{\circledR}$ course in the United Arab Emirates, a better performance in multiple-choice tests was observed among surgeons and emergency medical physicians compared to specialists who don't routinely treat trauma patients, showing that exposure to real scenarios improves knowledge ${ }^{24}$. Such an analysis highlights the need to implement trauma surgery residency programs, since they contribute knowledge of new procedures in trauma treatment as well as train residents in caring for critical patients ${ }^{13,25}$

In conclusion, the knowledge acquired by medical students belonging to the trauma league was greater in relation to NTL students for both applied questionnaires, with a dominance of this group in relation to the majority of subjects evaluated in this study, regardless of the stage of the undergraduate program. Therefore, the trauma league seems to be an alternative way to teach trauma surgery to medical students. 
Objetivo: comparar o conhecimento dos estudantes de Medicina da Liga do Trauma (LT) com os alunos Não Ligantes do Trauma (NLT), sobre os temas do atendimento ao trauma que os acadêmicos possuem maior domínio, avaliando a performance do conhecimento dos dois grupos. Métodos: estudo transversal, analítico, descritivo. Aplicou-se teste de conhecimento para os alunos do terceiro ao $12^{\circ}$ período. Desses, foram sorteados cinco acadêmicos de cada período, constituindo dois grupos: 50 no LT e 50 no NLT. Foram aplicados dois testes contento 30 questões para cada prova com os temas: atendimento pré-hospitalar, sequência mnemônica $A B C D E$ do trauma, condutas avançadas e imagem no trauma. Avaliou-se a performance dos estudantes por grupo de períodos da graduação: cadeira básica $\left(3^{\circ}-5^{\circ}\right.$ período), clínica $\left(6^{\circ}-8^{\circ}\right)$ e internato $\left(9^{\circ}-12^{\circ}\right)$. Resultados: no primeiro teste, a

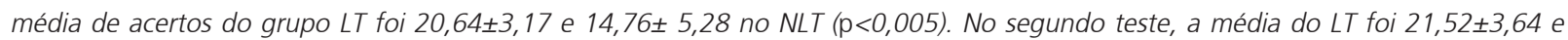
15,36 $\pm 5,29$ no NLT $(\mathrm{p}<0,005)$. O grupo LT teve maior média de acerto nas três cadeiras da graduação $(\mathrm{p}<0,05)$, nos dois testes. Conclusão: o grupo LT teve maior média de acerto em relação ao NLT e melhor aproveitamento dos temas estudados em todas as fases do curso médico.

Descritores: Trauma. Estudantes de Medicina. Ensino. Cirurgia Geral.

\section{REFERENCES}

1. World Health Organization. Injuries [Página da internet]. 2014 [Acessado em: 5 mai 2014]. Disponível em: http://www.who.int/ topics/injuries/en/.

2. World Health Organization (WHO). Injuries and violence: the facts. Geneva: WHO; 2010.

3. Brasil. Ministério da Saúde. Portal da Saúde. Inventimento na Saúde pretende reduzir óbitos e sequelas decorrentes de traumas [Internet]. 2012. [Acessado em: 5 mai 2014]. Disponível em: http://www.brasil.gov.br/saude/2012/08/investimento-na-saudepretende-reduzir-obitos-e-sequelas-decorrentes-de-traumas.

4. Reichenhein ME, de Souza ER, Moraes CR, de Mello Jorge MH, da Silva CM, de Souza Minayo MC. Violence and injuries in Brazil: the effect, progress made, and challenges ahead. Lancet. 2011;377(9781):1962-75.

5. Wainselfisz JJ. Mapa da violência 2013. Homicídios e juventude no Brasil. Brasília, DF: Secretaria Nacional de Juventude; 2013.

6. Fraga GP. Programas de qualidade no atendimento ao trauma. Medicina. 2007;40(3):321-8.

7. Committee to develop the Reorganized Specialty of Trauma, Surgical Critical Care, and Emergency Surgery. Acute care surgery: trauma, critical care, and emergency surgery. J Trauma. 2005;58(3):614-6.

8. Lampert JB. Currículo de graduação e o contexto da formação do médico. Rev Bras Educ Med. 2001;25(1):7-19.

9. Taquette SR, Costa-Macedo LM, Alvarenga FB. Currículo paralelo: uma realidade na formação dos estudantes de medicina da UERJ. Rev bras educ méd. 2003:27(3):171-6

10. Tavares AP, Ferreira RA, França EB, Fonseca Jr CA, Lopes GC, Dantas NGT, et al. O "currículo paralelo" dos estudantes de medicina da Universidade Federal de Minas Gerais. Rev bras educ méd. 2007;31(3):254-65.

11. Hamamoto Filho PT, Villas-Bôas PJF, Corrêa FG, Muñoz GOC, Zaba $M$, Venditti VC, et al. Normatização da abertura de ligas acadêmicas: a experiência da Faculdade de Medicina de Botucatu. Rev Bras Educ Med. 2010;34(1):160-7.

12. Santana ACDA. Ligas acadêmicas estudantis: o mérito e a realidade. Medicina. 2012;45(1):96-8.

13. Fraga GP, Collet-Silva FS, Souza HP. Mais cirurgiões, menos trauma. Rev Col Bras Cir. 2013;40(4):267-8.

14. Bitencourt AGV, Neves FBCS, Durães L, Nascimento DT, Neves NMBC, Torreão LA, et al. Avaliação do conhecimento de estudantes de medicina sobre morte encefálica. Rev bras ter intensiva. 2007;19(2):144-50.
15. Nascimento DT, Dias MA, Mota RS, Barberino L, Durães L, Santos PAJ. Evaluation of extracurricular internships in adult's intensive care units. Rev bras ter intensiva. 2008;20(4):355-61

16. Papp KK, Miller FB. A required trauma lecture series for junior medical students. J Trauma. 1995;38(1):2-4

17. Ali J, Cohen R, Adam R, Gana TJ, Pierre I, Ali E, et al. Attrition of cognitive and trauma management skills after the Advanced Trauma Life Support (ATLS) course. J Trauma. 1996;40(6):860-6.

18. Mohammad A, Branicki F, Abu-Zidan FM. Educational and clinical impact of Advanced Trauma Life Support (ATLS) courses: a systematic review. Word J Surg. 2014;38(2):322-9.

19. Williamson K, Ramesh R, Grabinsky A. Advances in prehospital trauma care. Int J Crit Illn Inj Sci. 2011;1(1):44-50.

20. American College of Surgeons. Resources for the optimal care of the injured patient: 2006. Chicago, IL: American College of Surgeons; 2006

21. Maegele M, Schöchl H, Cohen MJ. An update on the coagulopathy of trauma. Shock. 2014:41 Suppl 1:21-5.

22. Simões RL, Duarte Neto C, Maciel GSB, Furtado TP, Paulo DNS. Atendimento pré-hospitalar à múltiplas vítimas com trauma simulado. Rev Col Bras Cir. 2012;39(3):230-7.

23. Kelly E, Rogers SO Jr. Graduate medical education in trauma/ critical care and acute care surgery: defining goals for a new workforce. Surg Clin North Am. 2012;92(4):1055-64.

24. Abu-Zidan FM, Mohammad A, Jamal A, Chetty D, Gautam SC, van Dyke $M$, et al. Factors affecting success rate of Advanced Trauma Life Support (ATLS) courses. World J Surg. 2014;38(6):1405-10.

25. Spain DA, Miller FB. Education and training of the future trauma surgeon in acute care surgery: trauma, critical care, and emergency surgery. Am J Surg. 2005;190(2):212-7.

Received on 15/11/2013

Accepted for publication 03/01/2014

Updated 05/2014

Conflict of interest: none.

Source of funding: none.

\section{Corresponding author:}

Romeo Lages Simões

E-mail: romeolages@hotmail.com 